УДК 637.075:579.842.1/2

DOI: 10.15587/2313-8416.2015.35901

\title{
ВЕТЕРИНАРНО-САНІТАРНИЙ КОНТРОЛЬ МІКРОБІОЛОГІЧНИХ ПОКАЗНИКІВ ЯЛОВИЧИХ ТУШ ТА САНІТАРНИХ УМОВ ЇХ ВИРОБНИЦТВА
}

\author{
(C) В. В. Касянчук, О. М. Єфімова, О. М. Бергілевич, О. І. Скляр, В. Б. Кустуров
}

Визначено, щуо кількість бактерій родини Enterobacteriaceae та показник КМАФАнМ на поверхнях туш яловичини залежать від рівня санітарї на забійних підприємствах, від пори року, від місия відбору проб. Встановлено, щзо за умови належного рівня санітарії кількість бактерій родини Enterobacteri-

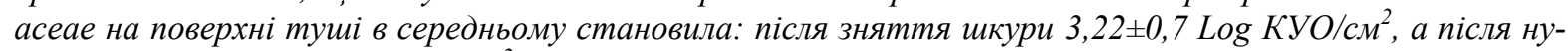

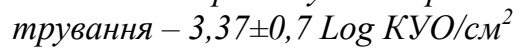

Ключові слова: яловичі туші, забійні підприємства, санітарія, Enterobacteriaceaе, КМАФАнМ, мікробіологічні критерії

It is determined that the number of Enterobacteriaceae family bacteria and total bacterial count (TBC) on the surfaces of beef carcasses depends on the level of sanitation in slaughterhouses, season and the sampling place. It is established that given an adequate level of sanitation the number of Enterobacteriaceae family bacteria on the surface of the carcass averaged: after skinning 3,22 $\pm 0,7 \mathrm{Log} \mathrm{CFU} / \mathrm{cm}^{2}$, and after evisceration $3,37 \pm 0,7 \mathrm{Log} C F U / \mathrm{cm}^{2}$

Keywords: beef carcasses, slaughterhouses, sanitation, Enterobacteriaceae, TBC, microbiological criteria

\section{1. Вступ}

Офіційна статистика свідчить, що яловичина займає вагому частку у секторі виробництві м'яса на Україні. Українська яловичина в більшій мірі експортується до інших країн порівняно із іншими видами м'яса. На користь яловичини свідчать також вподобання споживачів усього світу, які віддають перевагу саме м'ясу яловичини в своїх раціонах. Це пояснюється тим, що якісна яловичина має високі енергетичні та споживчі властивості. Крім того певні категорії населення не споживають свинину, і тому, теж віддають перевагу яловичині [1-5]. Звичайно, для того щоб вітчизняна яловичина була конкурентоспроможною на національному та міжнародних ринках, необхідно забезпечити іiі якість та безпечність. Вільний обіг продовольчих товарів в середині ЄC без прикордонного контролю між країнамичленами означає що в цих країнах правильно функціонують системи контролю харчових продуктів. Основна вимога, яку висуває ЄС до країн, які хочуть імпортувати свої харчові продукти, щоб вони відповідали таким самим високим стандартам, як і продукти, вироблені в межах СС.

Забезпечення розширення доступу української продукції на зовнішні ринки, насамперед до СС повинно відбуватись комплексно. В першу чергу повинно бути гармонізовано законодавство. В нашій країні в цьому напрямі зроблені важливі кроки. Так, до національного харчового законодавства було внесено важливі зміни у вигляді 3 -х нових законів, що прийняті 22 липня 2014, які стосуються запровадження єдиного контролюючого органу; підвищення відповідальності виробників; програм та планів державного контролю; перерозподілу повноважень та відповідальності між контролюючою організацією і виробником та ризик-орієнтрований підхід у офіційному контролі [6-8]. Всі зазначені зміни мають на меті привести українське законодавство в цій галузі у відповідність із харчовим законодавством $\mathrm{EC}$, а також сприяти більшій впевненості споживача у безпечності харчових продуктів, які він споживає. Слід відмітити, що основна відповідальність за безпечність продукції покладається на виробника, а офіційний контролюючий орган здійснює в більшості випадків аудиторські перевірки на предмет дотримання виробником вимог харчового законодавства. Виробник повинен контролювати виробництво своїх продуктів таким чином, щоб вони були безпечними, а офіційний орган повинен акцентувати на основні небезпеки що можуть мати місце у виробничому процесі. Тобто контроль повинен бути акцентованим на суттєвих ризиках. Ці ризики повинні бути визначені на науковій основі за спеціальною методологією. На таких ризиках також повинен бути зосереджений і офіційний контроль.

\section{2. Постановка проблеми}

Необхідно зазначити наступне, не дивлячись на те, що ризик орієнтований підхід в контролі хар- 
чових продуктів визначений в законодавстві України, на жаль, практичне здійснення контролю поки що не базується на таких ризиках. Це пов'язано 3 тим, що не має достатньо даних про наукову оцінку ризиків та не визначені пріоритетні ризики, які дійсно необхідно контролювати виробнику, щоб запобігти виникнення харчових отруєнь. Харчові ризики повинні визначатись постійно. Найбільш актуальним ризиком у виробництві яловичини є мікробіологічний. В Україні затверджені мікробіологічні критерії для харчових продуктів [9], які розроблені на основі відповідного Регламенту СС [10]. Цими критеріями в мікробіологічних вимогах до яловичини визначено контроль за такими показниками як КМАФАнМ та мікроорганізми родини Enterobacteriaceae. Вітчизняна яловичина на такий показник як бактерії родини Enterobacteriaceae не досліджується. У зв'язку цим, актуальним питанням є визначення ризику щодо мікроорганізмів цієї групи на тушах яловичини.

\section{3. Літературний огляд}

Огляд літератури був проведений, за час, що охоплює період 2000-2014, в тому числі проаналізовані нормативні та законодавчі акти в галузі продовольчої безпечності. Слід зазначити, що в наш час, в Україні широкими темпами відбувається налаштування усіх секторів економіки на відповідність вимогам міжнародних ринків. Особливо активно іде реформування продовольчого права, оскільки виробництво продовольчої сировини та харчових продуктів - це важлива галузь для економіки України. На жаль, в останні роки, в Україні існує тенденція переважання імпорту продовольства над експортом. Це пов'язано з недостатньою конкурентоспроможністю українських товарів, хоча аграрне виробництво України є тією галуззю, яка не в повній мірі реалізовує свій торговий потенціал.

Експорт продовольчих продуктів 3 України ускладнено через недостатньо гармонізоване харчове законодавство до вимог СС, а також неналежне його впровадження окремих його положень в національну економіку. Основна частина законодавства ЄС становлять директиви, а з 2002 р. найбільше значення в ньому мають технічні регламенти. Компетентний орган, що здійснює офіційний контроль за безпечністю харчових продуктів повинен керуватися в першу чергу такими основоположними Регламентами СС: №178/ 2002; №852/2004; №853/2004; № 854 /2004; №882 /2004; №2075/2005;№ 1774/2002 та інші [10-15].

Національне харчове законодавство визначає, що обов’язок держави це: створення гарантій безпеки для здоров'я людини під час виготовлення, ввезення, транспортування, зберігання, реалізації, використання, споживання, утилізації або знищення харчових продуктів і продовольчої сировини. В новому законодавстві України з'явилися такі терміни як: аналіз ризику, оцінка ризику, управління ризиком, що в значній мірі стосується державного контролю та нагляду та, в тому числі, ветеринарного. Згідно чинного законодавства ЄС та України компетентні органи не є відповідальними за безпечність та якість продукції, а тільки перевіряють дотримання вимог законодавства виробниками та примушують до виконання $[6-8,16]$.

На даний час європейське та національне законодавства базуються на 2-х основних принципах:

- відповідальність субєктів, що працюють на ринку продовольчих товарів та кормів, за суворе дотримання усіх положень продовольчого права;

- здійсненя офіційного контролю за діяльностю підприємств продовольчого сектора для встановлення його відповідності вимогам харчового законодавства.

3 введенням нового харчового законодавства в Україні створюється єдиний компетентний орган, який $є$ відповідальним за здійснення державного контролю безпечності харчових продуктів та започатковується підхід щодо здійснення державного контролю на ризик-орієнтованому підході із встановленням індивідуальної частоти перевірок для кожної потужності в залежності від ступеня ризику [6-8].

У державному ветеринарно-санітарному контролі в зв'язку з цим, повинні бути відповідні зміни. В першу чергу, це стосується підходу на основі ризику, який повинен здійснюватись на наукових дослідженнях. Також суттєва зміна в ролі ветеринарної служби у здійснені інспектування,яке повинно базуватись на контролі за процесами [6-8].

При виробництві яловичини, забійні та переробні підприємства повинні брати на себе більше практичної відповідальності за безпечність продукції Предметом їх основної уваги повинні бути харчові патогени: сальмонела, кишкова паличка, лістерія тощо.

Харчові патогени при виробництві продовольчої сировини та харчових продуктів на міжнародному рівні контролюються особливо ретельно. Це пов'язано з тим, що за даними ВОО3 щороку в світі 1,8 людей помирають від захворювань, причиною яких $\epsilon$ харчові продукти, контаміновані E.coli O 157 H7, кампілобактерії, лістерії, ієрсінії, що були в спожитих харчових продуктах. У США реєструється 100 млн випадків харчових захворювань на рік $[1,2,4,13]$. При контролі за харчовими патогенами користуються відповідними мікробіологічними критеріями.

В 2005 р Регламентом СС № 2073/2005 були запроваджені нові мікробіологічні критерії для харчових продуктів, які включали критерії безпосередньо для харчових продуктів та критерії гігієни їх виробництва [10].

В цьому Регламенті СС визначено що при контролі виробництва яловичини необхідно визначати критерії гігієни виробничого процесу.

Як видно з табл. 1 для встановлення відповідного стану гігієни виробничого процесу, необхідно визначити загальний рівень занасінення туш мікроорганізмами, та мікроорганізмами родини Enterobacteriaceae. Підрахунок цих мікроорганізмів, які зазвичай називаються індикаторними мікроорганізмами передбачає визначення рівня санітарного стану туш та гігієни на забійному чи м'ясопереробному 
підприємстві, а також дає можливість для прогнозування появи патогенних мікроорганізмів. Особливо інформативними в цьому плані $\epsilon$ бактерії родини Enterobacteriaceae, оскільки до іiі складу входить багато видів бактерій, і в тому числі такі як сальмонели та E.coli. Серед останніх можуть бути патоген- ні види, що є небезпечними для людей. В Україні також затверджені аналогічні критерії [9]. Слід відмітити, що в Україні ще не використовується європейський підхід контролю яловичини на основі визначення бактерій родини Enterobacteriaceae.

Мікробіологічні критерії, що визначають рівень гігієнічної обробки (Регламент ЄС № 2073/2005) [10]

\begin{tabular}{|c|c|c|c|}
\hline \multirow{8}{*}{$\begin{array}{c}\text { Туші яловичі, свині та дрі- } \\
\text { бної рогатої худоби }\end{array}$} & Показник & Критерії & Оцінка стану гігієни \\
\hline & \multirow{3}{*}{$\begin{array}{c}\text { Загальна кількість } \\
\text { мікроорганізмів } \\
\text { (КМАФАнМ) }\end{array}$} & $<3,5 \mathrm{Log} \mathrm{KYO} / \mathrm{cm}^{2}$ & добре \\
\hline & & $3,5-5,0 \mathrm{Log} \mathrm{KУO} / \mathrm{cm}^{2}$ & задовільно \\
\hline & & $>5,0 \mathrm{Log} \mathrm{KYO} / \mathrm{cm}^{2}$ & незадовільно \\
\hline & \multirow[t]{4}{*}{ Enterobacteriaceae } & & \\
\hline & & $<1,5 \mathrm{Log} \mathrm{KУO} / \mathrm{cm}^{2}$ & добре \\
\hline & & $1,5-2,5 \mathrm{Log} \mathrm{KУO} / \mathrm{cm}^{2}$ & задовільно \\
\hline & & $<2,5 \mathrm{Log} \mathrm{KУO} / \mathrm{cm}^{2}$ & незадовільно \\
\hline
\end{tabular}

Запровадження підходу наукової оцінки ризику пояснюється тим, що на даний час виникають все нові й нові мікробіологічні ризики, як відповідь на зміни у технології утримання, годівлі тварин та інновації в переробній промисловості, а також на використання нових засобів санітарії та гігієни, тощо. Все це призводить до виникнення стійких в довкіллі відомих видів мікроорганізмів, появи нових мікроорганізмів та нових проявів захворювань тварин, що в свою чергу негативно відображається на безпечності продукції тваринництва та впливає на загострення ситуації щодо спалахів харчових отруєнь. Крім того, необхідність оцінки ризику обгрунтовано тим що рівень мікробіологічної небезпеки в продовольчій продукції може мати різний регіональний, кліматичний та сезонний прояв. Тому в кожній країні повинні здійснюватись моніторингові та спеціальні наукові дослідження щодо оцінки мікробіологічного ризику харчових продуктів. Мікробіологічна оцінка ризику передбачає встановлення виду мікроорганізму, що викликає спалахи харчових отруєнь в людей, проведення повної характеристики його властивостей. Отримані результати наукової оцінки рівня мікробіологічного ризику використовуються відповідним офіційним органом управляння харчовими ризиками для розробки відповідних заходів для забезпечення безпечності продукції тваринництва для споживачів.

Ветеринарно-санітарна інспекція виробництва м'яса тварин також повинна базуватися на оцінці тих ризиків, які з великою долею вірогідності можуть бути присутніми в м'ясі та викликати харчові отруєння.

В Україні вивчено ступінь поширення та етіологічну структуру харчових токсикоінфекцій. Установлено взаємозв'язок між рівнем контамінації продуктів тваринництва, потенційними збудниками токсикоінфекцій і станом епідеміологічної ситуації. Найпоширенішими збідниками токсикоінфекцій в Україні є сальмонели, кишкові палички. До яловичини харчові патогени можуть потрапити від тварин, а також 3 довкілля $[1,2,4,5,16]$. При вивченні розповсюдження E.coli O 157 Н7 в господарствах різних адміністративних регіонів України було встановле- но, що шиготоксинпродукуючі E.coli виявлені серед BPX у 60 \% обстежених тваринницьких ферм. Носіями даної патогенної групи ешерихій в більшості випадків є ВРX $[17,18]$.

При вивчені мікробіологічних показників поверхні яловичих туш, визначив, що рівень контамінації їх мікроорганізмами залежить від виду туалету. При цьому він зазначає, що найбільша кількість мікроорганізмів відмічається на тушах, в яких було проведено вологий туалет. Туші, які оброблені сухим туалетом були менш контаміновані мікроорганізмами та краще зберігалися [2,3].

Отже, при підведенні підсумку огляду літератури, можна заключити, що Україна стала членом ВТО та підписала Угоду про перспективи членства в ЄС. Вимогою цих країн $є$ необхідність того, що країна-експортер продовольчої продукції повинна продемонструвати та підтвердити, що вона застосовує до експортної продукції такі заходи та має той же рівень їх захисту як і в країні, в яку направляється продукція. Країни члени ВТО та ЄС для забезпечення безпечності продовольчої продукції керуються такими міжнародними стандартами як CODEX; OIE та харчовим законодавством. На європейському ринку крім цього ще використовуються стандарти СС і відповідні директиви та регламенти. В країніекспортері повинні бути стандарти щодо безпечності харчових продуктів, які є ідентичними до відповідних міжнародних. Власні стандарти можуть також мати і суворіші вимоги ніж міжнародні, але в такому разі, ці вимоги повинні бути науково обгрунтовані на основі оцінки ризику. На міжнародному ринку для яловичини існують дещо інші вимоги до ії мікробіологічної безпечності ніж в Україні. Для подолання цих розбіжностей необхідно проводити наукові дослідження, щоб визначити дійсні мікробіологічні небезпеки яловичини. У зв'язку із вищезазначеним, новим пріоритетом в здійсненні офіційного ветеринарно-санітарного контролю виробництва харчових продуктів повинна бути наукова оцінка ризику. Серед усіх відомих ризиків в харчових продуктах переважають мікробіологічні. В сирому м'ясі, та в тому числі, в яловичині мікробіологічними ри- 
зиками є сальмонели, кишкова паличка, лістерії тощо $[1,2,3,16,19,20]$.

Таким чином, згідно сучасних вимог, усі офіційні управлінські заходи, що направлені на забезпечення безпечності харчових продуктів повинні бути обгрунтовані доцільністю їх проведення на основі наукової оцінки рівня ризику щодо конкретної небезпеки. Тобто, науці надаються розвідувальні функцій щодо визначення того, яка небезпека на даний час $\epsilon$ ризиком для здоров'я споживачів та якими заходами необхідно боротися з нею на державному рівні. Оцінка мікробіологічного ризику - це особлива методологія яка дає змогу детально вивчити небезпеку та встановити ступінь ризику від неї для людей [21].

Отже, науковий підхід щодо ветеринарносанітарного контролю якості процесів виробництва м'яса забійних тварин та, в тому числі, яловичини полягає у встановленні обгрунтування важливих мікробіологічних ризиків на конкретних етапах його в виробництва. Нами проведені дослідження у зазначеному напрямку, що наведені нижче.

Метою наших досліджень було встановлення рівня загальної контамінації мікроорганізмами туш яловичини (КМАФАнМ) та, в тому числі, бактеріями родини Enterobacteriaceae та визначення основних санітарних умов середовища і процесів виробництва, які необхідні для отримання безпечної яловичини.

\section{4. Матеріал та методи досліджень}

Проби для досліджень відбирали з туш яловичих після забою на бійнях та м'ясопереробних підприємствах Київської та Одеської областей. Всього було взято в досліди 6 підприємств. Підприємства, на яких відбирали проби, ми умовно поділили на 2 групи: 3 належним рівнем санітарних умов та 3 неналежними умовами санітарії. Рівень санітарних умов визначали шляхом візуальної оцінки умов виробництва яловичини та наявності на підприємствах системи НАССР або «Належної гігієнічної практики». Крім того, визначали рівень санітарного стану кожного підприємства шляхом мікробіологічних досліджень поверхонь, що контактують 3 тушами, а також проб повітря [21].

Для досліджень яловичих туш використовували неруйнівний метод відбору змивів. Змиви відбирали в наступних місцях: шиї, лопатки, грудини (зовнішня та внутрішня сторона), стегон 3 площі $100 \mathrm{~cm}^{2}$. Змиві відбирали відповідно правил асептики, використовували фізіологічний розчин. Проби досліджували протягом 2-х - 12-ти год. Визначення показника КМАФАнМ здійснювали шляхом посіву на поживний агар для цих мікроорганізмів, а бактерій родини Enterobacteriaceae - на середовище Ендо. Кількість мікроорганізмів визначали шляхом звичайного підрахунку та 3 наступним переведенням цих значень десятичні логарифми [22].

\section{5. Результати дослідження}

Для оцінки мікробіологічного ризику щодо туш яловичини, першочергово необхідно визначити ступінь поширення тих мікроорганізмів, що вивчаються. Об'єктом наших досліджень були бактерії родини Enterobacteriaceae. Тому, першочергово, наші дослідження були спрямовані на вивчення рівня контамінації туш яловичих бактеріями родини Enterobacteriaceae після таких технологічних процесів забою, як зняття шкури та нутрування. Ці дослідження щодо контамінації поверхонь туш яловичини, ми провели за різних санітарних умов їх виробництва. В даній статті наводяться середні дані за наслідками наших досліджень (табл. 2, 3).

Таблиця 2

Результати дослідження поверхні туш яловичих на рівень їх контамінації бактеріями родини Enterobacteriaceae (підприємства групи А)

\begin{tabular}{|c|c|c|c|}
\hline Стадія процесу обробки туші & Місце відбору проб & $\log \mathrm{KYO} / \mathrm{cm}^{2}$ & $\mathrm{KУO} \times 10^{3} \mathrm{~cm}^{2}$ \\
\hline \multirow{6}{*}{ Після зняття шкури } & Шия & $3,28 \pm 0,4$ & $1,89 \pm 0,9$ \\
\hline & Лопатка & $3,13 \pm 0,7$ & $1,35 \pm 0,7$ \\
\hline & Зовнішня сторона грудної клітки & $3,19 \pm 0,2$ & $1,55 \pm 0,7$ \\
\hline & Черевна стінка зовнішня сторона & $3,29 \pm 0,3$ & $1,97 \pm 1,1$ \\
\hline & Стегно & $3,23 \pm 0,7$ & $1,73 \pm 0,4$ \\
\hline & Середнє значення & $3,22 \pm 0,5$ & $1,69 \pm 0,9$ \\
\hline \multirow{8}{*}{ Після нутрування } & Шия & $3,29 \pm 1,2$ & $1,97 \pm 0,3$ \\
\hline & Лопатка & $3,25 \pm 0,6$ & $1,79 \pm 0,6$ \\
\hline & Грудна клітка зовнішня сторона & $3,26 \pm 0,9$ & $1,81 \pm 0,7$ \\
\hline & Грудна клітка внутрішня сторона & $3,46 \pm 0,8$ & $2,91 \pm 0,7$ \\
\hline & Черевна стінка зовнішня сторона & $3,33 \pm 0,5$ & $2,14 \pm 0,9$ \\
\hline & Черевна стінка внутрішня сторона & $3,65 \pm 0,6$ & $3,49 \pm 0,9$ \\
\hline & Стегно & $3,32 \pm 0,9$ & $2,12 \pm 1,3$ \\
\hline & Середнє значення & $3,37 \pm 0,7$ & $2,32 \pm 0,7$ \\
\hline
\end{tabular}

Дані табл. 2 показують, що найбільша кількість бактерій родини Enterobacteriaceae на забійних підприємства 3 належними умовами санітарії та гігієни (підприємства групи А), встановлена на поверх- нях туш яловичини в таких ділянках: шия та черевна стінка. При чому, було відмічено підвищення рівня контамінації зазначеними мікроорганізмами поверхні туш після другої технологічної операції - нутру- 
вання. Якщо порівняти результати наших досліджень, $з$ міжнародними мікробіологічними критеріями, що встановлені для яловичих туш, то можна заключити, що в цілому рівень контамінації поверхні туш бактеріями родин Enterobacteriaceae на досліджуваних процесах був в межах цих критеріїв.

Дані табл. 3 свідчать, що найбільша кількість бактерій родини Enterobacteriaceae на забійних підприємства 3 не належними умовами санітарії та гігієни (підприємства групи Б) встановлена в таких ділянках: шия грудна та черевна стінка. Також як і за даними табл. 3, було відмічено підвищення рівня контамінації зазначеними мікроорганізмами поверхні туш після другої технологічної операції - нутрування. Внутрішні поверхні грудної та черевної стінок були в більшій мірі контаміновані бактеріями родини Enterobacteriaceae ніж зовнішні поверхні туш. Якщо порівняти результати наших досліджень, 3 міжнародними мікробіологічними критеріями, що встановлені для яловичих туш, то можна заключити, що рівень контамінації поверхні туш бактеріями родин Enterobacteriaceae на досліджуваних процесах був вищим ніж встановлено цими критеріями.

Таблиця 3

Результати дослідження поверхні туш яловичих на рівень їх контамінації бактеріями родини Enterobacteriaceae (Підприємства групи Б)

\begin{tabular}{|c|c|c|c|}
\hline Стадія процесу обробки туші & Місце відбору проб & $\log \mathrm{KVO} / \mathrm{cm}^{2}$ & KУO $\times 10^{3} \mathrm{~cm}^{2}$ \\
\hline \multirow{6}{*}{ Після зняття шкури } & Шия & $3,64 \pm 0,7$ & $4,38 \pm 0,9$ \\
\hline & Лопатка & $3,61 \pm 0,4$ & $4,05 \pm 0,6$ \\
\hline & Зовнішня сторона грудної клітки & $3,66 \pm 0,2$ & $4,55 \pm 0,4$ \\
\hline & Черевна стінка зовнішня сторона & $3,70 \pm 0,3$ & $4,97 \pm 0,8$ \\
\hline & Стегно & $3,63 \pm 0,4$ & $4,33 \pm 0,7$ \\
\hline & Середнє значення & $3,65 \pm 0,8$ & $4,46 \pm 0,6$ \\
\hline \multirow{8}{*}{ Після нутрування } & Шия & $3,71 \pm 1,2$ & $5,17 \pm 0,5$ \\
\hline & Лопатка & $3,68 \pm 0,6$ & $4,79 \pm 0,6$ \\
\hline & Грудна клітка зовнішня сторона & $3,69 \pm 0,7$ & $4,91 \pm 0,9$ \\
\hline & Грудна клітка внутрішня сторона & $3,72 \pm 0,7$ & $5,21 \pm 0,6$ \\
\hline & Черевна стінка зовнішня сторона & $3,76 \pm 0,8$ & $5,73 \pm 0,5$ \\
\hline & Черевна стінка внутрішня сторона & $3,82 \pm 0,6$ & $6,54 \pm 0,7$ \\
\hline & Стегно & $3,71 \pm 0,5$ & $5,19 \pm 0,9$ \\
\hline & Середнє значення & $3,73 \pm 0,7$ & $5,36 \pm 0,9$ \\
\hline
\end{tabular}

Перший блок наших досліджень був присвячений вивченню рівня санітарних умов на забійних та м'ясопереробних підприємствах. Дослідження були проведені в теплу пору року (літньо - осінні місяці) та в холодну пору року (весняно - зимові місяці). Тварини надходили з ветеринарними документами про стан здоров'я, а при зовнішньому огля- ді в них не було ознак захворювань. Підприємства 3 візуально належним рівнем санітарії об’єднували в групу А, а підприємства де відмічено порушення умов санітарі та гігієни -в групу Б. Повітря досліджували в зоні забою на відстані 0,5-1 м від туш седиментаційним методом на МПА. Результати досліджень наведено в табл. 4.

Таблиця 4

Результати досліджень рівня мікробного забруднення поверхонь контактних до туш яловичини та повітря в зоні забою ( КМАФАнМ та кількість бактерій родини Enterobacteriaceae, КУО / $\mathrm{cm}^{2}$ та Log /КУО см²)

\begin{tabular}{|c|c|c|c|c|c|c|c|c|}
\hline \multirow{5}{*}{$\begin{array}{c}\text { Об'єкт дослі- } \\
\text { дження }\end{array}$} & \multicolumn{4}{|c|}{ Весна-зима } & \multicolumn{4}{|c|}{ Літо-осінь } \\
\hline & \multicolumn{4}{|c|}{ Підприємства, група } & \multicolumn{4}{|c|}{ Підприємства, група } \\
\hline & \multicolumn{2}{|c|}{$A(n-18)$} & \multicolumn{2}{|c|}{ Б (n-18) } & \multicolumn{2}{|c|}{$A(n-18)$} & \multicolumn{2}{|c|}{ Б $(n-18)$} \\
\hline & $\begin{array}{c}\mathrm{KYO} \times 10^{6} \\
\mathrm{~cm}^{2}\end{array}$ & $\begin{array}{c}\log / \mathrm{KYO} \\
\mathrm{cm}^{2}\end{array}$ & $\mathrm{KУO} \times 10^{6}$ & $\begin{array}{c}\mathrm{Log} / \mathrm{KYO} \\
\mathrm{cm}^{2}\end{array}$ & $\begin{array}{c}\mathrm{KYO} \times 10^{6} \\
\mathrm{~cm}^{2}\end{array}$ & $\begin{array}{c}\mathrm{Log} / \mathrm{KYO} \\
\mathrm{cm}^{2}\end{array}$ & $\begin{array}{c}\mathrm{KУO} \times 10^{6} \\
\mathrm{~cm}^{2}\end{array}$ & $\begin{array}{c}\mathrm{Log} / \mathrm{KYO} \\
\mathrm{cm}^{2}\end{array}$ \\
\hline & \multicolumn{8}{|c|}{ КМАФАнМ } \\
\hline $\begin{array}{l}\text { Гаки для підві- } \\
\text { шування туш }\end{array}$ & $51,8 \pm 1,2$ & $7,71 \pm 1,1$ & $85,9 \pm 1,6$ & $7,93 \pm 1,1$ & $73,1 \pm 2,3$ & $7,86 \pm 1,3$ & $159,8 \pm 3,5$ & $8,20 \pm 1,1$ \\
\hline Ножі & $37,3 \pm 1,6$ & $7,57 \pm 0,5$ & $69,4 \pm 2,3$ & $7,84 \pm 1,2$ & $52,2 \pm 3,1$ & $7,71 \pm 1,1$ & $106,4 \pm 2,5$ & $8,02 \pm 1,6$ \\
\hline Руки персоналу & $3,1 \pm 0,02$ & $6,49 \pm 1,2$ & $5,1 \pm 0,9$ & $6,71 \pm 1,1$ & $6,9 \pm 0,1$ & $6,83 \pm 1,2$ & $12,2 \pm 0,1$ & $7,08 \pm 1,2$ \\
\hline \multirow[t]{2}{*}{$\begin{array}{l}\text { Повітря в зоні } \\
\text { забою }\end{array}$} & $25,5 \pm 0,6$ & $7,41 \pm 1,2$ & $47,5 \pm 1,1$ & $7,67 \pm 0,7$ & $37,3 \pm 1,3$ & $7,57 \pm 1,1$ & $68,9 \pm 1,4$ & $7,84 \pm 1,1$ \\
\hline & \multicolumn{8}{|c|}{ Бактерії родини Enterobacteriaceae } \\
\hline $\begin{array}{l}\text { Гаки для підві- } \\
\text { шування туш }\end{array}$ & $16,4 \pm 2,3$ & $7,21 \pm 1,9$ & $37,6 \pm 3,1$ & $7,57 \pm 1,3$ & $39,1 \pm 1,7$ & $7,59 \pm 1,5$ & $91,8 \pm 3,2$ & $7,96 \pm 1,3$ \\
\hline Ножі & $12,3 \pm 1,6$ & $7,09 \pm 0,6$ & $24,7 \pm 2,3$ & $7,39 \pm 1,5$ & $36,7 \pm 2,7$ & $7,56 \pm 1,7$ & $57,4 \pm 2,4$ & $7,75 \pm 1,8$ \\
\hline Руки персоналу & $0,8 \pm 0,05$ & $5,9 \pm 0,7$ & $1,2 \pm 0,08$ & $6,07 \pm 1,6$ & $1,9 \pm 0,2$ & $6,28 \pm 1,3$ & $2,3 \pm 0,8$ & $6,36 \pm 1,7$ \\
\hline $\begin{array}{l}\text { Повітря в зоні } \\
\text { забою }\end{array}$ & $7,5 \pm 0,9$ & $6,87 \pm 1,9$ & $12,3 \pm 1,02$ & $7,09 \pm 1,8$ & $19,5 \pm 1,6$ & $7,29 \pm 1,6$ & $26,3 \pm 1,9$ & $7,42 \pm 1,7$ \\
\hline
\end{tabular}


Результати досліджень, що представлені в таблиці 4 свідчать по те, що найбільш високий рівень контамінації мікроорганізмами відмічався на поверхнях гаків та ножів. Причому, більша кількість мікроорганізмів була на тих підприємствах, де візуально були виявлені порушення гігієни та санітарії. Також, більша кількість мікроорганізмів була відмічена в теплу пору року порівняно із більш холодними сезонами року. Необхідно також зазначити, що кількість бактерій родини Enterobacteriaceae була незначно меншою на досліджуваних об'єктах, ніж показник МАФАнМ. Це свідчить про те, що в складі МАФАнМ переважну кількість становлять бактерій родини Enterobacteriaceae.

Крім того, слід звернути увагу на те, що дані значень кількості мікроорганізмів, які наведені в табл. 2-4, ми представили у вигляді арифметичних цифрових виразів так і в десятичних логарифмах. Якщо порівняти цифрові значення, що отримані нами при дослідженнях, то можна заключити, що представлення даних в логарифмах сприймається більш легко через меншу кількість цифр, що полегшує сприйняття отриманих результатів. Тому, в більшості випадків в зарубіжній літературі, результати досліджень, що відображують кількість мікроорганізмів в харчових продуктах чи в змивах 3 об'єктів, представлені в логарифмах.

\section{6. Висновки}

1. Поверхні ножів та гаків були найбільш контамінованими бактеріями родини Enterobacteriaceae та КМАФАнМ порівняно 3 іншими досліджуваними нами контактними поверхнями. Причому, більша кількість мікроорганізмів на контактних до туш поверхнях була на тих підприємствах, де візуально були виявлені порушення правил гігієни та санітарії.

2. Поширення бактерій родини Enterobacteriaceae на поверхнях туш яловичини залежить від рівня гігієни та санітарії на забійних підприємствах, від пори року і їх кількість різниться залежно від місця відбору проб змивів. В більшій мірі контамінованими були поверхні туш, що отримані за неналежних санітарно-гігієнічних умов, на їх поверхні кількість бактерій родини Enterobacteriaceae перевищувала показники мікробіологічних критеріїв.

3. Встановлено, що рівень контамінації туш яловичих бактеріями родини Enterobacteriaceae після зняття шкури в середньому становить $3,22 \pm 0,7 \log \mathrm{KУO} / \mathrm{cm}^{2}$ за умови належної гігієни та санітарії під час забою, і $3,65 \pm 0,8 \mathrm{Log} \mathrm{KУO} / \mathrm{cm}^{2}$, якщо порушуються вимоги до гігієни та санітарії,

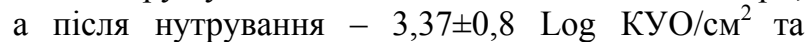
3,73 $\pm 0,8 \mathrm{Log}$ КУО/см² відповідно

4. Кількість бактерій родини Enterobacteriaceae на поверхні туші залежить від технологічної операції, сезону року та місця відбору проб змивів 3 поверхні туш. Найбільш контамінованими вищезазначеними мікроорганізмами були шийна частина та черевна стінка туш. В більшій мірі контамінування туш відбувається в теплі сезони року.

\section{Література}

1. Ветеринарно-санітарна експертиза та санітарна оцінка продуктів забою забійних тварин [Текст]: навч. посіб. / уклад. О. М. Якубчак, С. А. Ткачук, Р. І. Білик. Національний аграрний університет. - Київ, 2011. - 139 с.

2. Загребельний, В. О. Вплив способів заключної обробки туш на якість яловичини: монографія [Текст] / В. О. Загребельний, О. М. Якубчак, Т. В. Таран. - НУБіП України. - К. : Компринт, 2012. - 94 с.

3. Загребельний, В. О. Порівняльна характеристика сучасних методів відбору проб із туш тварин [Текст]/ В. О. Загребельний, О. М. Якубчак, І. М. Деркач // Біологія тварин. - 2012. - Т. 14, № 1. - С. 654-659.

4. Олійник, Л. В. Система моніторингу, контролю $\mathrm{i}$ профілактики токсикоінфекцій сальмонельозної та ешерихіозної етіологій [Текст]: дис... д-ра вет. наук: 16.00.09 / Л. В. Олійник. - УААН, Інститут ветеринарної медицини, 2004. -388 c.

5. Олійник, Л. В. Ветеринарно-санітарний контроль харчових токсикоінфекцій [Текст] / Л. В.Олійник. - Київ : Аграрна наука, 2004. - 200 с.

6. Закон України №4179а [Текст] / Про внесення змін до деяких законодавчих актів України щодо харчових продуктів, 2014.

7. Закон України №4986 [Текст] / Про Державний контроль у сфері забезпечення безпечності та якості харчових продуктів і кормів, благополуччя тварин, 2014.

8. Закон України №4055а [Текст] / Про побічні продукти тваринного походження, не призначених для споживання людьми, 2014.

9. Мікробіологічні критері для встановлення показників безпечності харчових продуктів [Текст] / НАКАЗ MO3 України 19.07.2012 № 548. - Зареєстровано в Міністерстві юстиції України 3.08 .2012 р. за № 1321/21633

\begin{tabular}{l} 
10. Регламент СC 2073/2005 [Текст] \\
\hline
\end{tabular} Мікробіологічні критерії для харчових продуктів.

11. Регламент № 178/2002 [Текст] / Свропейського парламенту i Ради від 28 січня 2002 року про встановлення загальних принципів і вимог законодавства про харчові продукти.

12. Регламент № 852/2004 [Текст] / Свропейського парламенту і Ради від 29 квітня 2004 року про гігієну харчових продуктів.

13. Регламент № 853/2004 [Текст] / Свропейського парламенту і Ради від 29 квітня 2004 року, що встановлює спеціальні правила гігієни для харчових продуктів тваринного походження.

14. Регламент № 854/2004 [Текст] / Європейського парламенту і Ради від від 29 квітня 2004 року, який встановлює конкретні правила 3 організації офіційного контролю продуктів тваринного походження, призначених для споживання людиною.

15. Регламент № 882/2004 [Текст] / Свропейського парламенту і Ради від 29 квітня 2004 року про офіційні заходи контролю, які застосовуються для перевірки відповідності законодавству про харчові продукти та корми, правилам здоров'я та благополуччя тварин.

16. Бергілевич, О. М. Визначення відповідності мікробіологічним критеріям харчових продуктів та виробничого процесу шляхом розробки плану відбору проб [Текст] / О. М. Бергілевич, В. В. Касянчук, Т. О. Гаркавенко, О. О. Каганець, О. О. Бергілевич, А. М. Марченко // Ветеринарна медицина України. - 2010. - № 7. - С. 33-36.

17. Зоценко, Л. В. Розповсюдження серед великої рогатої худоби i свиней шиготоксинпродукуючих ешерихій та вивчення їх біологічних властивостей [Текст]: автореф. дис ... канд. вет. наук: 16.00.03. / Л. В. Зоценко. К., 2003.- 18 c. 
18. Зоценко, Л. В. Токсигенні ізоляти Escherichia coli, виділені від хворих на діарею поросят [Текст] Л. В. Зоценко // Науковий вісник Національного аграрного університету. - 2000. - Вип.28. - С. 218-219.

19. Якубчак, О. М. Критерії оцінки якості м'яса : монографія [Текст] / О. М. Якубчак, В. В. Кравчук, Т. В. Таран. - Національний університет біоресурсів і природокористування України. - К. : КОМПРИНТ, 2013. $-120 \mathrm{c}$.

20. Якубчак, О. М. Наукові підходи щодо отримання молока та яловичини належної якості [Текст]: монографія / О. М. Якубчак, Л. О. Оленіч, А. І. Кобиш // Національний університет біоресурсів і природокористування України. - К. : КОМПРИНТ, 2013. $168 \mathrm{c}$.

21. Касянчук, В. В. Методичні рекомендації щодо встановлення відповідності мікробіологічним критеріям харчових продуктів та санітарно-гігієнічних умов виробничого процесу [Текст] / В.В.Касянчук, О. М. Бергілевич, Д. А. Засєкін, М. Д. Кухтін, Т. О. Гаркавенко, О. О. Бергілевич, О. О. Каганець, А. М. Марченко. - Затвердженні Вченою радою ДНДІ ЛДВСЕ (протокол № 3 від 20 квітня 2011p). -28 с.

22. Касянчук, В. В. Методичні рекомендації щодо обчислення значення біологічних логарифмів мікроорганізмів в харчовій мікробіології,продовольчій гігієні та санітарії [Текст] / В. В. Касянчук, О. М. Бергілевич, В. О. Загребельний, Т. О. Гаркавенко, І. В. Негай, В. Б. Кустуров, С. А. Гришина. - К., ДНДІЛДВСЕ, 2014. $-26 \mathrm{c}$.

\section{References}

1. Yakubchak, O. M., Tkachuk, S. A., Bilyk, R. I. (2011). Veterinary-sanitary examination and health assessment of products of slaughter slaughtered animals, teach. Guidances. National Agricultural University, Kyiv, 139.

2. Zahrebelny, V. A., Yakubchak, A. M., Taran, T. (2012). Effect of final processing methods on the quality of beef carcasses, monograph. NULES Ukraine, Kyiv: Komprynt, 94.

3. Zahrebelny, V. O., Yakubchak, A. M., Derkach, I. M. (2012). Comparative characteristics of modern sampling of animal carcasses. Animal biology, 14 (1), 654-659.

4. Oleynik, L. A. The system of monitoring, control and prevention of salmonellosis and toxic esheryhioznoyi etiolohiy. Agrarian Sciences, Institute of Veterinary Medicine. Kiev, 388.

5. Oleynik, L. V. (2004). Veterinary control of food poisoning. Kiev: Agricultural Science, 200.

6. Law of Ukraine №4179a (2014). On Amendments to Certain Legislative Acts of Ukraine regarding food.

7. Law of Ukraine №4986 (2014). On state control in the field of safety and quality of food and feed, animal welfare.

8. Law of Ukraine №4055a (2014). On animal byproducts not intended for human consumption.

9. Microbiological criteria for establishing indicators of food safety (2012). Order of Ministry of Health Ukrain № 548. Registered with the Ministry of Justice of Ukraine 3 .08.2012. According № 1321/21633.
10. Commission Regulation (EC) №2073 (2005). Microbiological criteria for foodstuff. Official Journal of the European Union, 26.

11. Regulation (EC) №178 of the European Parliament and of the Council (2002). Laying down the general principles and requirements of food law, establishing the European Food SafetyAuthorityand laying down procedures in matters of food safety. Official Journal of the European Union, $3 p$.

12. Regulation (EC) № 852 of the European Parliament and of the Council (2004). On the hygiene of foodstuffs. Official Journal of the European Union, 51.

13. Regulation (EC) № 853 of the European Parliament and of the Council (2004). Laying down specific hygiene rules for on the hygiene of foodstuffs. Official Journal of the European Union, 55.

14. Regulation (EC) № 854 of the European Parliament and of the Council (2004). Laying down specific rules for the organisation of official controls on products of animal origin intended for human consumption / Official Journal of the European Union, 45.

15. Regulation (EC) № 882 of the European Parliament and of the Council (2004). On official controls performed to ensure the verification of compliance with feed and food law, animal health and animal welfare rules. Official Journal of the European Union, 45.

16. Berhilevych, O. M., Kasyanchuk, V. V., Garkavenko, T. A., Kahanets, O. O., Berhilevych, O. A., Marchenko, A. M. (2010). Consistency with microbiological criteria of food production and by developing the sampling plan. Veterinary Medicine of Ukraine, 7, 33-36.

17. Zotsenko, L. V. (2003). Distribution of cattle and pigs shigotoxinproducing E. coli and the study of their biological properties. Kiev, 18.

18. Zotsenko, L. V. (2000) Toxigenic isolates of Escherichia coli, isolated from piglets with diarrhea. Scientific Bulletin of the National Agrarian University, 28, 218-219.

19. Yakubchak, O., Kravchuk, V., Taran, T. (2013). Criteria for assessing the quality of meat: monograph. NULES Ukraine, Kyiv: Komprynt, 120.

20. Yakubchak, O., Olenich, L., Kobysh, A. (2013). Scientific approaches to get milk and beef as appropriate. National University of Life and Environmental Sciences of Ukraine. NULES Ukraine, Kiev: Komprynt, 168.

21. Kasyanchuk, V. V., Berhilevych, O. M., Zasyekin, D. A., Kuhtin, M. D., Garkavenko, T. A., Berhilevych, O. A., Kaganets, O. O., Marchenko, A. M. (2011). Guidelines to establish compliance with microbiological criteria of food and sanitary conditions of the production process. State Research Institute of Laboratory Diagnostics and Veterinary Expertise (protocol №3 of 20 April 2011), 28

22. Kasyanchuk, V. V., Berhilevych, O. M., Zahrebelnyy, V. O., Garkavenko, T. O., Negai, I., Kusturov, V., Hryshyna, Y. A. (2014). Guidelines for calculating logarithms biological significance of microorganisms in food microbiology, food hygiene and sanitation. Kiev, State Research Institute of Laboratory Diagnostics and Veterinary Expertise, 26.

Касянчук Вікторія Вікторівна, доктор ветеринарних наук, професор, кафедра технології молока і м'яса, Сумський національний аграрний університет, вул. Григорія Кондратьєва, 160, м. Суми, Україна, 40021 
Сфімова Ольга Миколаївна, аспірант, Сумський національний аграрний університет, вул. Григорія Кондратьєва, 160, м. Суми, Україна, 40021

E-mail: kordon@vet.gov.ua

Бергілевіч Олександра Миколаївна, доктор ветеринарних наук, профессор, Кафедра технології молока і м'яса, Сумський національний аграрний університет, вул. Григорія Кондратьєва, 160, м. Суми, Україна, 40021

E-mail: bergilevich@ukr.net

Скляр Олександр Іванович, доктор ветеринарних наук, профессор, кафедра терапії, фармакології та клінічної діагностики, Сумський національний аграрний університет, вул. Григорія Кондратьєва, 160, м. Суми, Україна, 40021

E-mail: sklyar1956@yandex.ru

Кустуров Володимир Борисович, начальник, Одеська регіональна служба державного ветеринарносанітарного контролю та нагляду на кордоні та транспорті, вул. Боженко, 19, м. Одеса, Україна, 65009 E-mail: pvet@icn.od.ua 